\title{
Short- / Long-Term Deformation of Upper Crust: Integrated and Quantitative Approach for Neotectonics
}

\author{
Yasuto Itoh ${ }^{1}$, Shigekazu Kusumoto ${ }^{2}$, \\ Kazunori Miyamoto ${ }^{3}$ and Yoshiyuki Inui ${ }^{3}$ \\ ${ }^{1}$ Graduate School of Science, Osaka Prefecture University, \\ ${ }^{2}$ Graduate School of Science and Technology for Research, University of Toyama, \\ ${ }^{3}$ College of Integrated Arts and Sciences, Osaka Prefecture University \\ elopan
}

\section{Introduction}

The Japanese Islands are facing active convergent margin, and have suffered intense deformation. On 11 March 2011, accumulated stress on the Japan Trench was released as a catastrophic earthquake ( $\mathrm{Mw} 9.0)$, and the number of casualties are still increasing during preparation of this manuscript. The authors offer our deepest condolences on the loss of human lives, and dedicate this paper to the deceased hoping that our research can contribute to the advancement of integrated evaluation of seismic hazards.

The islands are divided into northeast and southwest Japan at the Itoigawa-Shizuoka Tectonic Line (ISTL; Figure 1), which is a remarkable geological break and a zone of highly active reverse faults. An area of extremely high strain rate is conventionally named as Central Japan, which is a mountainous province associated with a number of active faults/volcanoes. Based on geomorphological studies, distribution of active faults in Central Japan has been clarified in detail (Research Group for Active Faults, 1991). Countless Quaternary tephra are precisely correlated (Machida \& Arai, 2003), and serve to monitor subtle neotectonic deformation as explained in the following sections. It is an example of a junction of arcs (northeast Japan, southwest Japan and Izu-Bonin arcs), and an intensive collision zone. Remarkable bent of geologic belts, caused by collision of the Izu-Bonin arc, has been studied from the viewpoint of paleomagnetism / structural geology. Itoh \& Ito (1989) clarified process of ductile deformation of the crust since the Miocene on the basis of spatial distribution of vertical-axis rotation deduced from paleomagnetic data.

Long-term deformation in Central Japan is accommodated by conjugate strike-slip fault system; the NE-SW Atotsugawa fault system and NW-SE Atera fault system (Figure 1). Huzita (1980) proposed that they have been activated under an E-W compressive stress regime provoked during the Quaternary. Recently, paleomagnetic studies (Kimura et al., 2004; Itoh et al., 2008) revealed that rotation pattern around the active faults is simulated as deformation of continuous medium. Although temporal fluctuation of geomagnetic field (secular variation) generally hinders us from precise determination of tectonic rotation 
angles, Iwaki \& Hayashida (2003) indicated that the stable thermoremanent magnetization (TRM) of a welded pyroclastic flow deposit is an instantaneous record of geomagnetic field, and describes subtle Quaternary relative rotational motions after reliable correction of tectonic tilting.

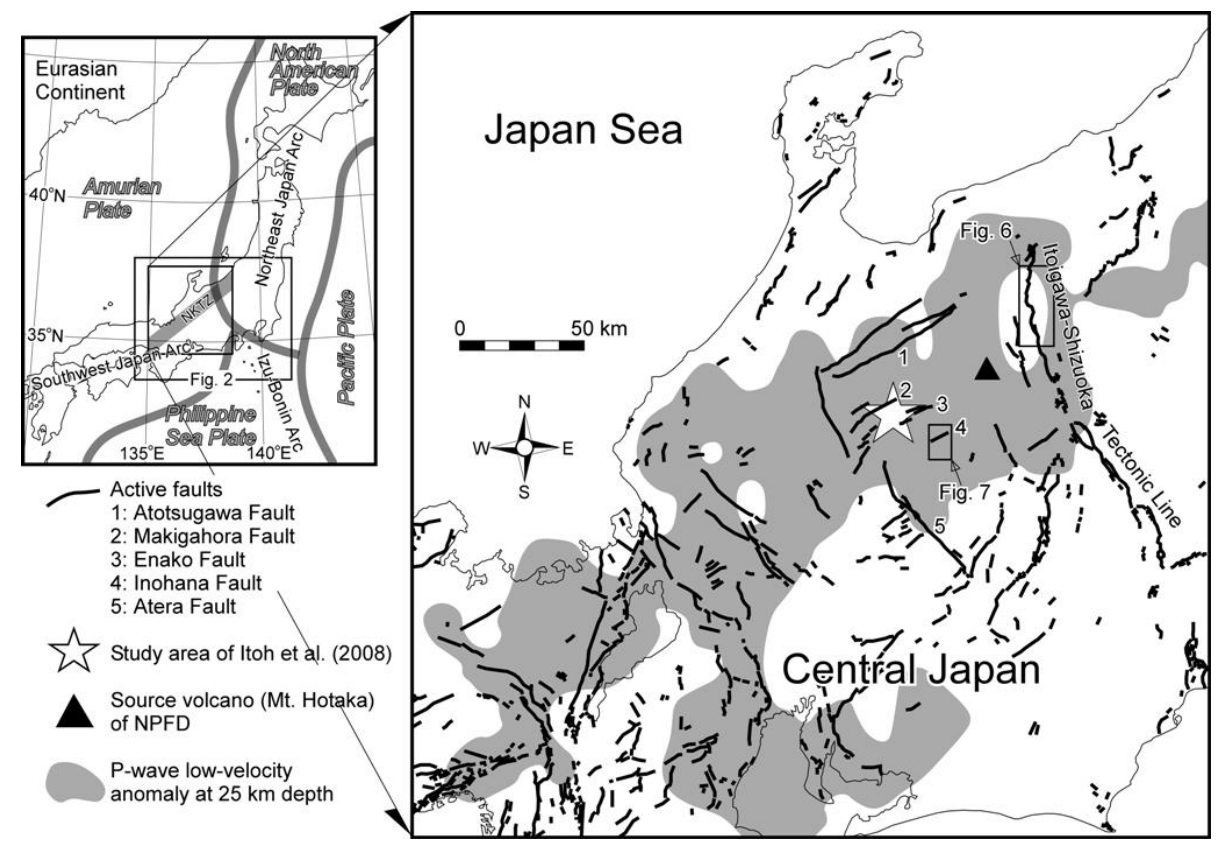

Fig. 1. Index maps of the study area. Distribution of active faults is shown after the Working Group for Compilation of 1:2,000,000 Active Faults Map of Japan (2000). P-wave lowvelocity anomaly (shaded zone) is after Nakajima \& Hasegawa (2007). Bold gray lines in the regional tectonic inset map are convergent plate boundaries (after Seno et al., 1996)

Because it is a province containing densely populated residential areas together with seismic/volcanic hazards, data of seismic activities and crustal strain have been acquired utilizing a nation-wide observation network. Since 1990s, geodetic analyses based on triangulation data over a century (Hashimoto \& Jackson, 1993) and GPS data during recent decades (Sagiya et al., 2000; Sagiya, 2004; Toya \& Kasahara, 2005) have delineated a zone of high strain rate; Niigata-Kobe Tectonic Zone (NKTZ) accompanied by vigorous seismic activity. The NE-SW NKTZ (regional index of Figure 1) roughly overlaps a right-lateral active faults zone (Atotsugawa fault system) in Central Japan, implying a contribution to the strong Quaternary deformation around the study area. A tomographic research (Nakajima \& Hasegawa, 2007) found a mid-crust low-velocity portion underlying the NKTZ (Figure 1). Therefore, the tectonic zone does not only act as short-term deformation front but also has significance in a geologic time-scale. Although quantitative description of deformation pattern is essential to elucidate evolutionary process of the intra-crust seismogenic zone, its long-term cumulative strain has not been addressed on the basis of geologic studies. Hence the authors attempt to assess the consistency between short- and long-term deformation 
modes of the upper crust in the Japanese Archipelago, and test the feasibility of and problems in the general procedures of tectonic study.

\section{Short-term study: detection of tectonic zones based on geodesy and its evaluation based on seismology}

\subsection{Synopsis}

Neotectonic crustal deformation caused upon a convergent margin is regarded as an accumulation of instantaneous plate motions, and thus can be evaluated on the basis of precise geodetic data. Recent geodetic studies in Japan cast a doubt whether the ISTL is the governing deformation front in recent periods. Sagiya et al. (2000) detected a zone of high strain rate (> 10-7 strain/year; strain rate of the surrounding areas is approximately $10^{-8}$ strain/year) extending from Niigata to Kobe along the Japan Sea coast, namely NKTZ, through an analysis of dense GPS network data. In addition, based on a robust and exploratory analysis of the dense GPS data, Toya \& Kasahara (2005) found that the NKTZ is accompanied with clockwise rotation provoked by shear stress. This tectonic zone is approximately $100 \mathrm{~km}$ wide and extends along this line for up to $500 \mathrm{~km}$ in a NE-SW orientation, which is crossing the N-S trending ISTL. Existence of this zone has also been pointed out in 1990s by analysis of triangulation data for the past 100 years (Hashimoto, 1990; Hashimoto \& Jackson, 1993).

\subsection{Seismic activities}

Many large earthquakes have occurred in and around this tectonic zone in recorded history. Recently, the large earthquakes (e.g., 1995 Mw 7.2, Hyogoken-Nanbu (south Kobe); 2004 Mw 6.6, Niigata-Chuetsu; 2007 Mw 6.8, Off Niigata-Chuetsu; 2007 Mw 6.9, Noto Peninsula) have occurred. Latest activity (Mw 6.6, hypocenter=Niigata) in the NKTZ was on 12 March 2011, ca. 13 hours later than the devastating earthquake on the Pacific plate margin (Mw 9.0). Causal research between the consecutive seismic events is still under way. Thus, it has been suggested that the present deformation field has persisted for the last several hundred years at least (Sagiya et al., 2000) and that this zone is regarded as the plate boundary between the Amurian plate and the North American plate (see inset of Figure 1 for plate configuration around the Far East region) (Sagiya et al., 2000; Shimazaki \& Zhao, 2000; Miyazaki \& Heki, 2001; Heki \& Miyazaki, 2001; Mazzotti et al., 2000) or a boundary between the Amurian plate and an island arc (Mazzotti et al., 2000).

\subsection{Origin of the neotectonic deformation zone}

The origin of the NKTZ has been studied by many authors, and there are two basic ideas roughly. One is interpretation based on interplate deformation and the other one is interpretation based on intraplate deformation. Shimazaki \& Zhao (2000) regarded the NKTZ as a colliding plate boundary, and discussed the observed high strain rates in terms of interplate deformation by dislocation modeling based on Savage (1983). On the other hand, lio et al. (2002) regarded the NKTZ as being not a plate boundary but an internal deformation zone near the eastern margin of the Amurian plate, and proposed a model of which a weak zone with low viscosity exists in the lower crust immediately beneath the NKTZ. Hyodo \& Hirahara (2003) examined the model proposed by lio et al. (2002) using a $3 \mathrm{D}$ finite element modeling, and showed that the observed high strain rates along the NKTZ 
can be explained by the crustal structure that consist of weak upper crust with half rigidity of the surrounding crust and of the viscoelastic lower crust of $15 \mathrm{~km}$ thickness having almost the same viscosity at the upper mantle. By a 2D finite element modeling, Yamasaki \& Seno (2005) evaluated the effect of which rheological heterogeneities in the lower crust or upper mantle would give to the surface deformation, and indicated that the observed high strain rates can be reproduced by a low-viscosity upper mantle immediately beneath and trenchward of the NKTZ.

\subsection{Subsurface structure of the deformation zone}

Many subsurface structures based on seismic tomography study in and around the NKTZ have been shown in any scales (e.g., Wang \& Zhao, 2006; Nakajima \& Hasegawa, 2007; Xia et al., 2008; Iidaka et al., 2009; Kato et al., 2010). Nakajima \& Hasegawa (2007) estimated deep crustal structure beneath the NKTZ and divided this zone into three regions on the basis of the velocity structure. The first is region of which low-velocity anomaly lies in the lower crust along the NKTZ, and the second is region of which there is a prominent low velocity anomaly extending from lower crust to the uppermost mantle, and the third is region of which low-velocity anomalies exist in the upper crust and in the uppermost mantle. The results given by Nakajima \& Hasegawa (2007) support basically models and ideas suggested by lio et al. (2002), Hyodo \& Hirahara (2003) and Yamasaki \& Seno (2005).

\section{Long-term study: extent of tectonic zones based on paleomagnetism}

\subsection{Synopsis}

Deformation mode of the crust in convergent plate margins reflects complicated tectonic processes. Cumulative deformation is described by means of geologic structure (faults and folds), and, more specifically, vertical-axis rotation can be detected on the basis of paleomagnetic analysis. Central Japan has been a typical field of such investigation, because it is characterized by quite high strain rate expressed as rapid mountain building and active faulting.

Recently, GPS data from plate boundary zones (e.g., Greece) have been used to describe deformation process in conjunction with tectonic rotation patterns inferred from paleomagnetic data. Because of the secular variation of the geomagnetic field, observational scatter in remanent magnetization has hindered the determination of precise rotational motions in previous studies (e.g., Mattei et al., 2004). Therefore paleomagnetic researchers in Japan (e.g., Iwaki \& Hayashida, 2003; Itoh et al., 2008) focused on pyroclastic flow deposits and their correlative and widespread tephra. Previous studies (Reynolds, 1979; Hayashida et al., 1996) have demonstrated that fresh welded pyroclastic flow deposits preserve stable TRM as an instantaneous record of the geomagnetic field, the measured directions of which are identical with those of detrital remanent magnetization (DRM) of correlative coignimbrite ashes in remote areas. Reflecting active subduction of plates, many vigorous volcanoes are distributed in Central Japan. TRM/DRM of Quaternary pyroclastic flow deposits and correlated widespread tephra show easterly deflection from an expected direction, suggesting significant clockwise rotation. Thus, the rotational mode described on the basis of the GPS analysis seems to last through the Quaternary. 


\begin{tabular}{|c|c|c|c|c|c|}
\hline Unit & Age (Ma) & $\mathrm{R} \pm \Delta \mathrm{R}\left(^{\circ}\right) /[\mathrm{R}]$ & Data & Reference & Province (area) \\
\hline \multicolumn{6}{|l|}{ Inside NKTZ } \\
\hline Takagariyama I, II & $1.76,1.75$ & {$[4.7 \sim 66.7]$} & A & Kd39, Kd38 & Omine (1) \\
\hline Nyukawa & 1.76 & {$[-13.9 \sim 47.8]$} & A & $\mathrm{Kd} 39$ & Takayama (2) \\
\hline Kamitakara (upper) & 0.60 & $40.8 \pm 7.7$ & B & Ks22 & Takayama (3) \\
\hline Nyukawa & 1.76 & [10.0 89.9] & $\mathrm{C}$ & Kd39 & Takayama (4) \\
\hline Ebisutoge & 1.75 & $15.3 \pm 16.2$ & $\mathrm{D}$ & $\mathrm{Kd} 38$ & Takayama (5) \\
\hline Nyukawa & 1.76 & {$[4.8 \sim 69.7]$} & E & $\mathrm{Kd} 39$ & Takayama (6) \\
\hline Eboshidake & $1.5 \sim 1.2$ & {$[-33.7 \sim 120.9]$} & $\mathrm{F}$ & dipole field & Eboshidake (7) \\
\hline Shiratsuchidani & 1.03 & indeterminate $^{*}$ & G & Pink V.A. & Lake Biwa (8) \\
\hline \multicolumn{6}{|l|}{ Outside NKTZ } \\
\hline Tsujimatagawa & 1.75 & $1.7 \pm 17.6$ & $\mathrm{D}$ & $\mathrm{Kd} 38$ & Niigata (9) \\
\hline Shigarami & $5.9 \sim 4.4$ & $-11.0 \pm 14.0$ & $\mathrm{H}$ & dipole field & Sai River (10) \\
\hline Otogawa / Mita & $10 \sim 2$ & $-0.1 \pm 6.2$ & I & dipole field & Yatsuo (11) \\
\hline Ao / Yabuta & $6 \sim 3$ & $-0.3 \pm 5.7$ & $\mathrm{~J}$ & dipole field & Himi (12) \\
\hline Karegawa & 1.75 & $-0.2 \pm 15.7$ & $\mathrm{D}$ & $\mathrm{Kd} 38$ & Mie (13) \\
\hline Kitawaki & 1.75 & 1.3 & $\mathrm{D}$ & $\mathrm{Kd} 38$ & Lake Biwa (14) \\
\hline Fukuda / Fugenji & 1.75 & $-0.9 \pm 15.3$ & $\mathrm{D}$ & $\mathrm{Kd} 38$ & Kyoto / Osaka (15) \\
\hline
\end{tabular}

Table 1. Compilation of paleomagnetic data in Central Japan since the late Miocene Data are sorted roughly from east to west for the areas inside and outside NKTZ, respectively. $\mathrm{R}$ (positive/negative values mean CW/CCW rotation) is defined by Beck (1980), uncertainty of which is given based on Demarest (1983). $\Delta \mathrm{R}$ for the Kitawaki V.A. is not shown because of small number of sites. In some areas, ranges of $\mathrm{R}$ values for site-mean paleomagnetic directions are shown in brackets, because scatter of vector directions skewed by differential rotations is not reasonably estimated on the basis of Fisher statistics. Data are after: A, this study; B, Itoh \& Kimura (2004); C, Itoh et al. (2003); D, Iwaki \& Hayashida (2003); E, Itoh et al. (2008); F, Itoh et al. (2007); G, Itoh \& Danhara (2008); H, Niitsuma et al. (2003); I, Itoh \& Hayakawa (1988); J, Itoh \& Watanabe (1997). * As for the Shiratsuchidani V.A., range of $\mathrm{R}$ is not shown, because the reference data (Pink V.A.) itself has large scatter linked to neotectonic rotation.

The authors have reviewed previous paleomagnetic data around Central Japan since the late Neogene (Itoh \& Danhara, 2008; Itoh \& Hayakawa, 1988; Itoh \& Kimura, 2004; Itoh \& Watanabe, 1997; Itoh et al., 2003, 2007, 2008; Iwaki \& Hayashida, 2003; Niitsuma et al., 2003), in an effort to delineate an area of cumulative subtle crustal deformation. Reliable paleomagnetic data accompanied with correction of tectonic tilt, age assignments and progressive demagnetization tests are listed in Table 1, and spatial distribution of the data is presented in Figure 2. It is clearly noted that the areas of significant clockwise rotation are aligned in a NE-SW orientation, and fairly accords with the geodetically detected shear 
deformation zone. In order to avoid confusion raised by using the same term for tectonic zones defined on different bases, we name the paleomagnetically detected deformation zone as the Central Japan Shear Zone (CJSZ), although sparse distribution of the paleomagnetic data is not enough to define precise border of the CJSZ.

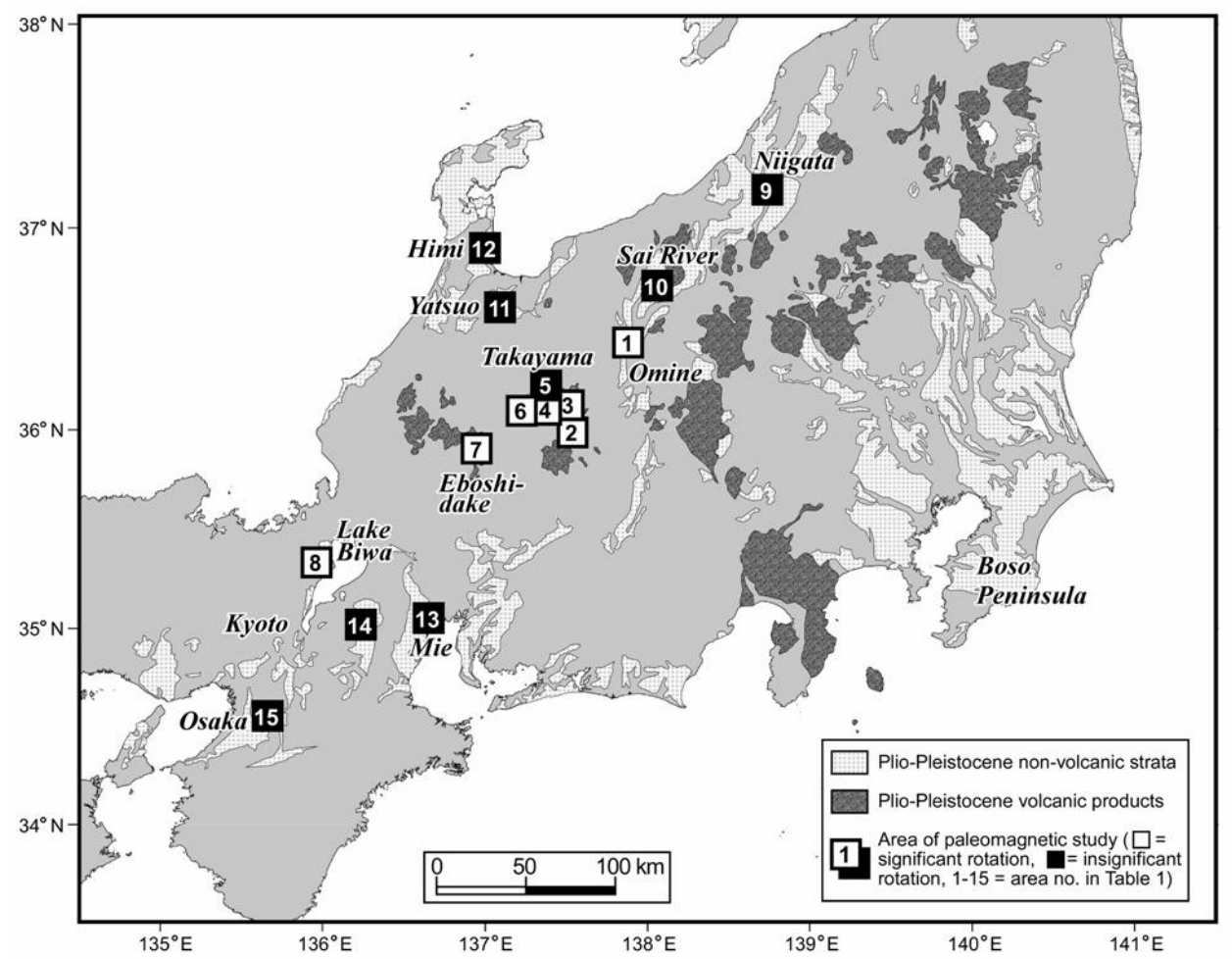

Fig. 2. Neotectonic clockwise rotation in Central Japan based on paleomagnetism. See Table 1 for data source and amount of rotational motions

In this section, we present a new early Quaternary paleomagnetic dataset obtained from the eastern flank of the ISTL, which gives us an insight for evaluation of the crisscrossing paradoxical neotectonic zones; north-trending ISTL and northeast-trending CJSZ (or NKTZ).

\subsection{Geology}

Reflecting strong contraction on the ISTL, Neogene-Quaternary on its eastern flank is exposed as a fault-bounded N-S elongated tilted block. It is collectively named as the Omine Belt (Kosaka \& Arai, 1982). Among the numerous volcaniclastic layers intercalated within the fluvial sequences, two glassy ashes (Takagariyama I and II) were correlated with extensive Quaternary pyroclastic flow deposits in Central Japan and widespread tephra (Figure 3) by Nagahashi et al. (2000). They stated that the volcanic products occurred just above the Olduvai Subchronozone. 


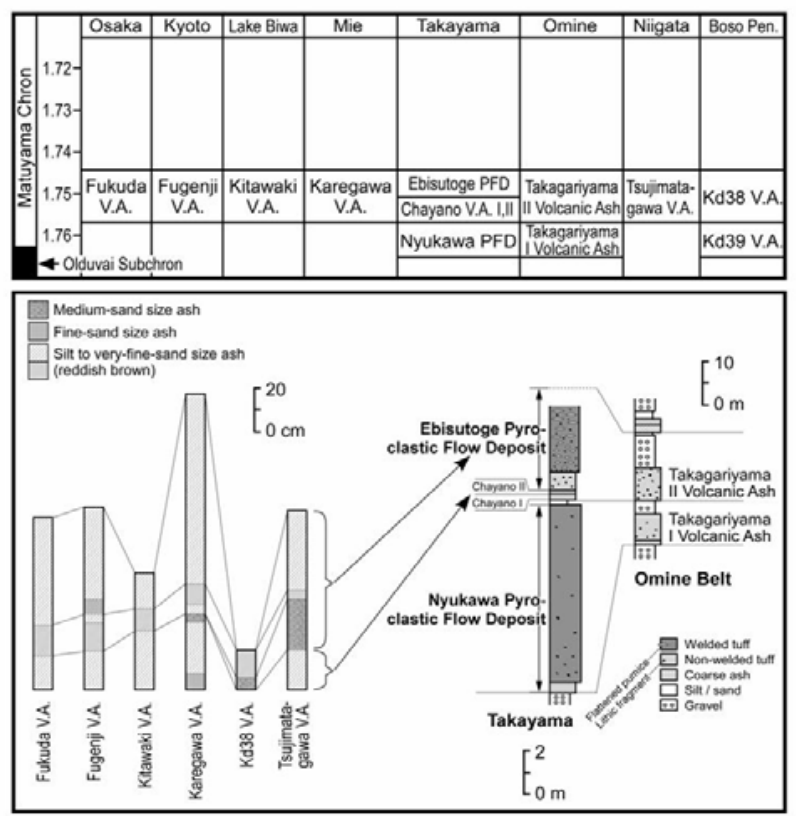

Fig. 3. Correlation of Quaternary pyroclastic flow deposits and widespread tephra around Central Japan (Nagahashi et al., 2000). See Fig. 2 for provinces, Table 1 for geologic units

\subsection{Paleomagnetism}

Volcaniclastic samples were obtained from 13 sites in the study area. In each site, 10 17 cores were obtained using an electric drill, and independently oriented by a magnetic compass. We prepared 12 28 standard-sized specimens $(25 \mathrm{~mm}$ in diameter and $22 \mathrm{~mm}$ in height) for each site. For all specimens, bulk initial susceptibility was measured using a magnetic susceptibility meter (Bartington MS-2). Natural remanent magnetization (NRM) was measured using a spinner magnetometer (Schonstedt SSM-1) or a cryogenic magnetometer (model 760-R SRM, 2-G Enterprises).

Stable remanent magnetization residing in samples was isolated through progressive thermal demagnetization (PThD) experiment up to $680{ }^{\circ} \mathrm{C}$. Specimens were heated in air using a non-inductively wound electric furnace. Residual magnetic field within the samplecontaining space of the furnace, which is covered by multi-layered $\mu$-metal envelopes, was less than $10 \mathrm{nT}$. Typical results of demagnetization tests are shown in Figure 4. A stable primary component of remanent magnetization is expressed as a linear trend converging to the origin of a vector-demagnetization diagram or a confined plot on an equal-area projection. Since the magnetic directions were not changed after demagnetization at the Curie temperature of magnetite $\left(\sim 580{ }^{\circ} \mathrm{C}\right)$, stable remanence of the present samples is probably carried by dominant titanomagnetite and a small amount of ilmenohematite. As a result, we obtained characteristic remanent magnetization (ChRM) from the two ash layers as listed in Table 2. 

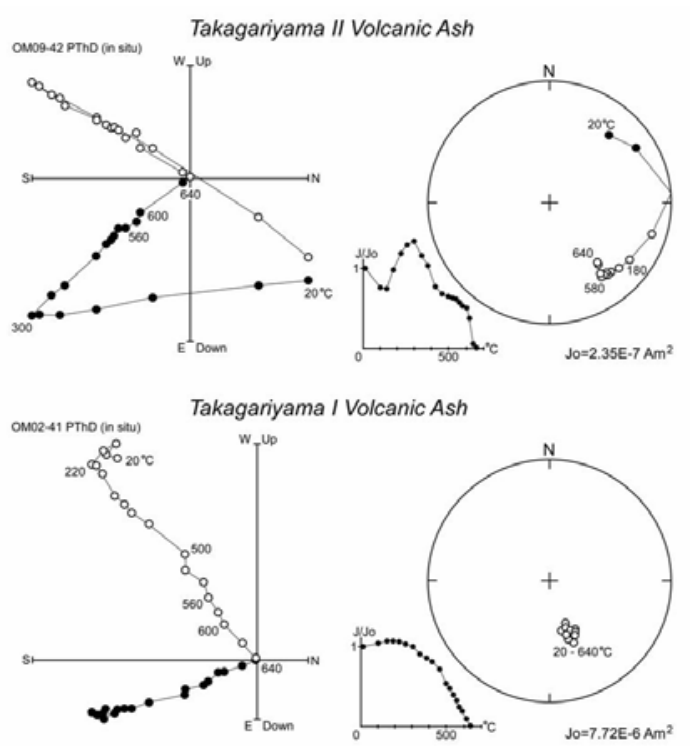

Fig. 4. Vector-demagnetization diagrams (left) and equal-area nets (right) for volcanic ash samples on the eastern flank of the ISTL. As for vector diagrams, solid (open) symbols are projections of vector endpoints on the horizontal (N-S vertical) plane in the in situ coordinates. Unit of coordinates is bulk remanent intensity. As for equal-area nets, solid (open) symbols are plotted on the lower (upper) hemisphere

\begin{tabular}{|l|l|l|l|l|l|l|l|l|l|l|}
\hline Site & Method & $\mathrm{D}\left(^{\circ}\right)$ & $\mathrm{I}\left(^{\circ}\right)$ & $\mathrm{Dc}\left(^{\circ}\right)$ & $\mathrm{Ic}\left({ }^{\circ}\right)$ & $\alpha_{95}\left(^{\circ}\right)$ & $\kappa$ & $\mathrm{N}$ & $\phi\left(^{\circ}\right)$ & $\lambda\left(^{\circ}\right)$ \\
\hline Takagariyama II Volcanic Ash \\
\hline OM04 & PCA & -171.3 & -62.2 & -101.8 & -55.9 & 2.8 & 384.7 & 8 & 29.0 & -157.9 \\
\hline OM09 & GCF & 171.1 & -31.0 & -155.2 & -46.6 & 1.5 & 408.0 & 24 & 67.4 & -116.9 \\
\hline OM11 & PCA & -178.0 & -54.2 & -163.5 & -52.0 & 4.6 & 172.7 & 7 & 75.9 & -121.0 \\
\hline OM12 & PCA & 168.5 & -71.7 & -163.8 & -58.5 & 2.4 & 393.5 & 10 & 77.0 & -148.8 \\
\hline TakagariyamaI Volcanic Ash & Ash \\
\hline OM02 & PCA & 146.6 & -46.8 & -172.6 & -56.5 & 3.1 & 221.4 & 11 & 84.0 & -140.4 \\
\hline OM03 & PCA & 178.1 & -46.5 & -145.2 & -51.5 & 1.6 & 1217.0 & 8 & 61.1 & -133.8 \\
\hline
\end{tabular}

Table 2. Magnetic directions obtained from the Takagariyama Volcanic Ash layers

PCA and GCF in calculation method of magnetic direction are principal component analysis and great circle fitting, respectively; D and I are in situ site-mean declination and inclination, respectively; Dc and Ic are untilted site-mean declination and inclination, respectively; $\alpha_{95}$ is the radius of $95 \%$ confidence circle; $\kappa$ is Fisher's precision parameter; $\mathrm{N}$ is the number of specimens; $\phi$ and $\lambda$ are the latitude $(\mathrm{N})$ and the longitude $(\mathrm{E})$ of the north-seeking virtual geomagnetic pole of the untilted site-mean magnetic direction, respectively. 


\subsection{Tectonic implications}

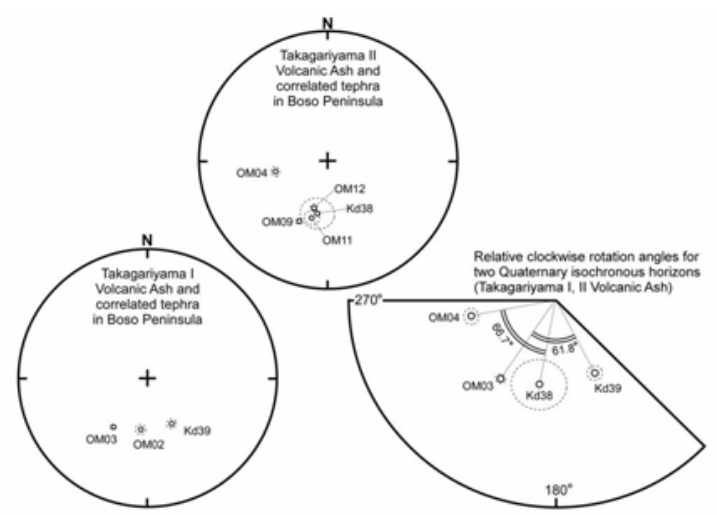

Fig. 5. Site-mean ChRM directions of the Quaternary tephra on the eastern flank of the ISTL together with reference directions in the Boso Peninsula (Iwaki \& Hayashida, 2003;

Nagahashi et al., 2000). Open symbols on the equal-area projections are on the upper hemisphere. Dotted ovals are limit of $95 \%$ confidence

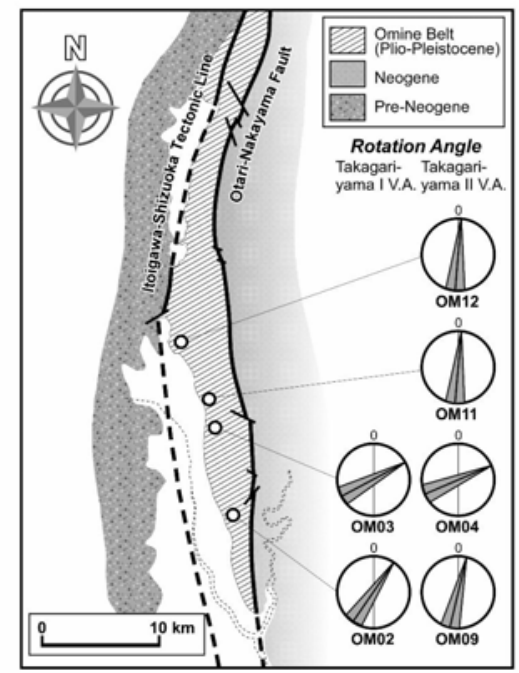

Fig. 6. Spatial distribution of rotational motions upon the eastern flank of the ISTL (Omine Belt). Geologic map is simplified after Kosaka \& Arai (1982). See Fig. 1 for the mapped location

Site-mean ChRM directions of the Quaternary tephra in the Omine Belt are plotted on equalarea projections together with reference directions obtained from correlated tephra in the Boso Peninsula (Figure 5). Spatial distribution of the rotational motion is shown on the simplified geologic map of Figure 6. Tilt-corrected declinations of the samples show 
deflection from the reference, implying clockwise rotation around a vertical axis. We regard that the significant deflection is not attributed to a superficial landslide or flow-induced deflection of DRM direction but to a tectonic rotation because of a concordant rotational motions of the two data horizons. As shown in Figure 5 (right), ChRM directions of the Takagariyama I (OM03) and II (OM04) obtained from a sampling route exhibit identical rotation angles from reference directions, a fact which suggests block rotation later than accumulation of the fluvial sequence. Spatial distribution of rotational motions (see Figure 6) implies that the northern part of the study area is out of the CJSZ.

As shown in this case study, even in an area out of the distribution of pyroclastic flow deposits, stratigraphic correlation enables us to determine contemporaneous paleomagnetic directions of tephra derived from the same source vent as the pyroclastic flows. The authors have presented new paleomagnetic data of early Quaternary widespread tephra distributed on the eastern flank of the ISTL, of which stable remanent magnetization shows significant easterly deflection from an expected direction, thus, tectonic clockwise rotation is certified as correct regardless of the contractional activity on the ISTL. Further research is necessary for the understanding of temporal change in deformation modes.

\section{Closer look on deformation modes: advanced paleomagnetic study}

\subsection{Synopsis}

Closer look on the differential rotation pattern implies progressive segmentation of upper crust along a master fault and deformation of rotated blocks bounded by nested-faults, presence of which was confirmed through field survey. Itoh et al. (2003) clarified that paleomagnetic directions of an extensive Pleistocene (see Figure 3 for the stratigraphic position) pyroclastic flow deposit (Nyukawa Pyroclastic Flow Deposit; NPFD) distributed on the active Enako fault showed a cyclic fluctuation in amount of vertical-axis rotation, which is controlled by a deformation of nested fault blocks. Itoh \& Amano (2004) executed an intensive paleomagnetic analysis of rotational motions within a large granitic pluton along an underground drift in northeast Japan, and found that a progressive segmentation of upper crust on a fault is accompanied with differential rotation of faulted blocks around three orthogonal axes. It is, therefore, important to describe rotation patterns in detail for the understanding of the deformation process of the study area.

Upon the western flank of the ISTL, the Atotsugawa fault and the Inohana fault (see Figure 1) lie along the northern and southern limits of the dextral shear zone, NKTZ, respectively, which is coincident with an area of clockwise rotation based on the GPS analysis. In this section, we focus on modes of tectonic rotation around the southern Inohana fault because paleomagnetism of the early Pleistocene NPFD (Figure 7), which has been utilized for neotectonic study (e.g., Itoh et al., 2008) as a result of its extensive distribution and stable magnetization, may delineate deformation and rotation pattern around the margin of a significant paleomagnetic shear zone, CJSZ. We aim to describe an incipient tectonic zone with small cumulative strain, which is significant for the understanding of recent tectonic regime.

\subsection{Geology}

As a result of steady plate subduction, Central Japan has been a site of vigorous arc volcanism. Among numerous pyroclastic flow deposits, the early Quaternary NPFD (1.76 
Ma, Nagahashi et al., 2000) and late Quaternary Kamitakara Pyroclastic Flow Deposit have the most extensive distribution, and their paleomagnetic directions have been reported by many researchers. The present study deals with the NPFD erupted from the Mt. Hotaka (Figure 1), because it is scattered around the southern border of the geodetically defined NKTZ. The NPFD is a dacitic pyroclastic flow deposit scarcely accompanied with visible eutaxitic structure. It consists of a single cooling unit (Yamada et al., 1985), and then, of which remanence is regarded as TRM synchronously acquired during initial rapid cooling. Our sampling areas (Figure 7) are out of the areas of the previous paleomagnetic studies.

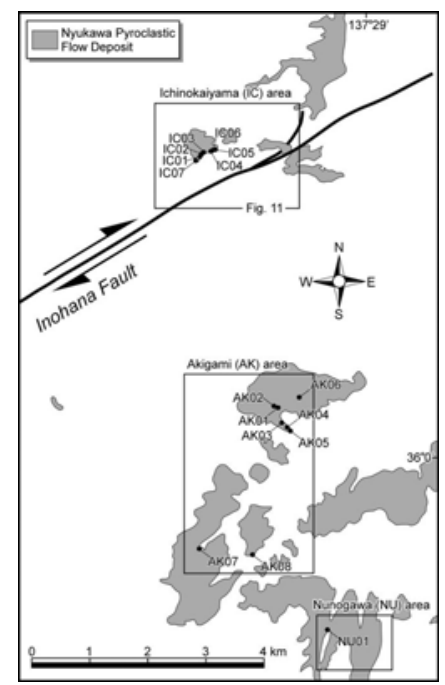

Fig. 7. Sampling areas for paleomagnetic study on the western flank of ISTL. Distribution of the Nyukawa Pyroclastic Flow Deposit (NPFD) and trace of the Inohana Fault are after Yamada et al. (1985) and Yamada \& Kobayashi (1988). See Fig. 1 for the mapped location

The NKTZ is partly parallel to the Atotsugawa fault system and numerous NE-SW active dextral faults in the northern part of Central Japan. Among such faults, deformation pattern has been intensively studied around the Enako fault (Figure 1) that has high slip rate and contributed for formation of an intermontane pull-apart basin together with en echelon Makigahora fault (Kimura et al., 2004; Itoh et al., 2003, 2008). There is a NE-SW fault roughly running along the southern margin of the NKTZ; named as the Inohana fault (Figures 1 and 7). It has a moderate level of activity with dominantly right-lateral offset as large as $850 \mathrm{~m}$ (Research Group for Active Faults, 1991). In order to evaluate the fault-related neotectonic deformation, paleomagnetic sampling was executed in the Ichinokaiyama (IC) and Akigami (AK) / Nunogawa (NU) areas on the northern and southern sides of the Inohana fault, respectively (Figure 7). Except for a non-welded tuff taken in the NU area, all the samples are densely welded.

\subsection{Paleomagnetism}

Since the eutaxitic structure for correction of tectonic tilt is affected by topographic relief of bed rocks, we avoided basal part of the pyroclastic flow deposit referring to results of 
geological survey. In each site, 8 12 cores were obtained using an engine drill or an electric drill, and independently oriented by a magnetic compass. We prepared 16 31 standardsized specimens, for which measurements of bulk initial susceptibility and NRM on a spinner magnetometer (Schonstedt SSM-1) were executed as explained in the previous section. Anisotropy of initial magnetic susceptibility (AMS) was also determined for all specimens upon a KappaBridge system (KLY-3S). Site-mean AMS parameters are listed in Table 3.

\begin{tabular}{|c|c|c|c|c|c|c|c|c|c|c|c|}
\hline Site & $\mathrm{N}$ & $\mathrm{K}_{1}$ & $\mathrm{~K}_{2}$ & $\mathrm{~K}_{3}$ & (Dec., Inc.) & $\mathrm{L}$ & $\mathrm{F}$ & $\mathrm{P}$ & $\mathrm{P}_{\mathrm{J}}$ & $\mathrm{T}$ & $q$ \\
\hline \multicolumn{12}{|c|}{ Ichinokaiyama (IC) area } \\
\hline IC01 & 31 & 1.017 & 1.005 & 0.978 & $(323,18)$ & 1.011 & 1.028 & 1.040 & 1.041 & 0.420 & 0.345 \\
\hline IC02 & 21 & 1.012 & 1.005 & 0.983 & $(355,69)$ & 1.008 & 1.022 & 1.030 & 1.031 & 0.468 & 0.311 \\
\hline IC03 & 16 & 1.010 & 1.006 & 0.985 & $(313,65)$ & 1.004 & 1.021 & 1.025 & 1.027 & 0.692 & 0.169 \\
\hline IC04 & 11 & 1.010 & 1.000 & 0.990 & $(343,59)$ & 1.010 & 1.010 & 1.020 & 1.020 & -0.009 & 0.679 \\
\hline IC05 & 16 & 1.010 & 1.003 & 0.987 & $(271,64)$ & 1.007 & 1.017 & 1.024 & 1.025 & 0.392 & 0.362 \\
\hline IC06 & 9 & 1.012 & 1.005 & 0.982 & $(328,41)$ & 1.007 & 1.024 & 1.031 & 1.032 & 0.543 & 0.262 \\
\hline IC07 & 19 & 1.018 & 1.010 & 0.973 & $(273,80)$ & 1.008 & 1.038 & 1.046 & 1.049 & 0.651 & 0.195 \\
\hline \multicolumn{12}{|c|}{ Akigami $(A K)$ area } \\
\hline AK01 & 16 & 1.015 & 1.003 & 0.982 & $(86,62)$ & 1.012 & 1.021 & 1.034 & 1.034 & 0.256 & 0.463 \\
\hline AK02 & 17 & 1.008 & 1.008 & 0.984 & $(277,85)$ & 1.000 & 1.024 & 1.024 & 1.028 & 0.975 & 0.013 \\
\hline AK03 & 16 & 1.016 & 1.006 & 0.978 & $(78,84)$ & 1.011 & 1.029 & 1.040 & 1.041 & 0.450 & 0.324 \\
\hline AK04 & 16 & 1.005 & 1.004 & 0.992 & $(211,81)$ & 1.001 & 1.012 & 1.013 & 1.015 & 0.841 & 0.083 \\
\hline AK05 & 20 & 1.007 & 1.003 & 0.989 & $(75,78)$ & 1.004 & 1.014 & 1.018 & 1.019 & 0.556 & 0.252 \\
\hline AK06 & 13 & 1.007 & 1.006 & 0.987 & $(134,84)$ & 1.002 & 1.019 & 1.021 & 1.023 & 0.849 & 0.079 \\
\hline AK07 & 19 & 1.006 & 1.003 & 0.991 & $(78,81)$ & 1.003 & 1.012 & 1.015 & 1.016 & 0.577 & 0.238 \\
\hline AK08 & 16 & 1.009 & 1.008 & 0.983 & $(289,64)$ & 1.001 & 1.025 & 1.027 & 1.030 & 0.900 & 0.052 \\
\hline \multicolumn{12}{|c|}{ Nunogawa (NU) area } \\
\hline NU01 & 24 & 1.003 & 1.003 & 0.994 & $(35,83)$ & 1.001 & 1.009 & 1.009 & 1.010 & 0.848 & 0.079 \\
\hline
\end{tabular}

Table 3. Site-mean AMS parameters of the Nyukawa Pyroclastic Flow Deposit. N denotes the number of specimens

In order to isolate stable remanent magnetization, PThD was executed up to $640{ }^{\circ} \mathrm{C}$. Specimens were heated in air using an electric furnace as explained in the previous section. Figure 8 presents typical results of the PThD test. As for the IC and AK areas, the NRM of the NPFD shows a linear trend converging to the origin of vector-demagnetization diagrams with reversed polarity, accompanied by subtle secondary overprint demagnetized under $300{ }^{\circ} \mathrm{C}$. We interpret that the component with lower unblocking temperature $\left(\mathrm{T}_{\mathrm{UB}}\right)$ is a secondary viscous component acquired during recent geologic period, and the higher $\mathrm{T}_{\mathrm{UB}}$ component is a primary TRM acquired in the Matuyama Chron. Directions of the stable component were determined on the basis of a three-dimensional least squares technique (Kirschvink, 1980). Site-mean TRM directions are listed in Table 4. 


\begin{tabular}{llllllllllll}
\hline Site & Tilting (data/method) & $\mathrm{D}\left(^{\circ}\right)$ & $\mathrm{I}\left({ }^{\circ}\right)$ & $\mathrm{Dc}\left({ }^{\circ}\right)$ & $\mathrm{Ic}\left({ }^{\circ}\right)$ & $\alpha_{95}\left(^{\circ}\right)$ & $\kappa$ & $\mathrm{N}$ & $\phi\left(^{\circ}\right)$ & $\lambda\left(^{\circ}\right)$ \\
\hline \multicolumn{1}{l}{ Ichinokaiyama(IC) area } & & & & & & & & & & \\
IC01 & N53E72S/AMS & 156.6 & -6.1 & -167.2 & -72.2 & 3.8 & 116.9 & 13 & 67.1 & 155.4 \\
IC02 & N80W7S/thin sec. & -178.5 & -47.3 & -179.9 & -54.2 & 2.7 & 353.1 & 9 & 88.7 & -46.1 \\
IC03 & N43E25E/AMS & 147.2 & -46.4 & 162.5 & -69.8 & 3.8 & 182.4 & 9 & 68.6 & 108.2 \\
IC04 & N73E31S/AMS & -173.6 & -20.3 & -163.4 & -47.8 & 3.4 & 225.1 & 9 & 74.3 & -110.1 \\
IC05 & N1E26E/AMS & 170.4 & -49.8 & -159.2 & -47.6 & 9.4 & 27.6 & 10 & 71.0 & -115.7 \\
IC06 & N58E49S/AMS & 168.8 & -11.7 & -174.2 & -55.5 & 0.6 & 6338.6 & 85.3 & -134.1 \\
IC07 & N4E7E/thin sec. & 168.6 & -46.4 & 176.0 & -47.8 & 1.0 & 2660.5 & 8 & 82.1 & -16.2 \\
Akigami & AK) area & & & & & & & & & & \\
AK01 & N4W28W/AMS & 176.4 & -58.2 & 139.1 & -48.8 & 1.1 & 2299.8 & 5 & 55.3 & 49.0 \\
AK02 & N34E10E/thin sec. & 176.8 & -56.8 & -168.5 & -61.8 & 1.6 & 999.2 & 9 & 78.7 & -174.3 \\
AK03 & N12W6W/AMS & 177.9 & -55.3 & 169.1 & -55.9 & 1.3 & 1555.2 & 81.2 & 53.6 \\
AK04 & N59W9N/AMS & 162.8 & -51.1 & 169.8 & -44.6 & 1.4 & 1311.7 & 76.9 & 2.0 \\
AK05 & N15W12W/AMS & 174.6 & -55.2 & 157.2 & -55.4 & 1.0 & 2765.4 & 71.6 & 54.0 \\
AK06 & N44E6W/AMS & -178.0 & -59.5 & 175.4 & -55.2 & 0.9 & 3891.3 & 8 & 86.3 & 44.6 \\
AK07 & N12W9W/AMS & 172.7 & -55.9 & 159.4 & -55.5 & 1.7 & 873.3 & 9 & 73.4 & 53.7 \\
AK08 & Horizontal/outcrop & 166.6 & -65.1 & 166.6 & -65.1 & 2.8 & 336.8 & 9 & 75.1 & 99.8 \\
\hline
\end{tabular}

Table 4. Magnetic directions obtained from the Nyukawa Pyroclastic Flow Deposit

$\mathrm{D}$ and I are in situ site-mean declination and inclination, respectively; Dc and Ic are untilted site-mean declination and inclination, respectively; $\alpha_{95}$ is the radius of $95 \%$ confidence circle; $\kappa$ is Fisher's precision parameter; $N$ is the number of specimens; $\phi$ and $\lambda$ are the latitude $(N)$ and the longitude (E) of the north-seeking virtual geomagnetic pole of the untilted site-mean magnetic direction, respectively.
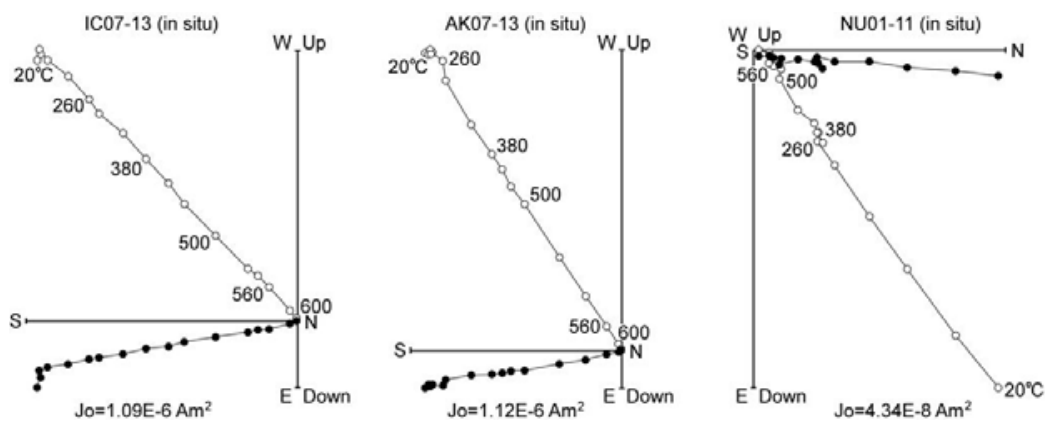

Fig. 8. Typical vector-demagnetization diagrams of progressive thermal demagnetization (PThD) for the NPFD distributed in the IC, AK and NU areas. See Fig. 7 for sampling areas. Solid and open symbols are vector end-points projected on the horizontal and N-S vertical planes, respectively. All diagrams are shown in geographic coordinates. Units are bulk remanent intensity 
As for the non-welded tuff obtained from the NU area, PThD showed presence of a stable normal component parallel to the recent geomagnetic field (Figure 8). Because welded blocks of the NPFD were often found in tuff outcrops along the Nunogawa River route, we regard the component as a DRM acquired during redepositional event in the Brunhes Chron. Hence the NU area is excluded from the following analysis.
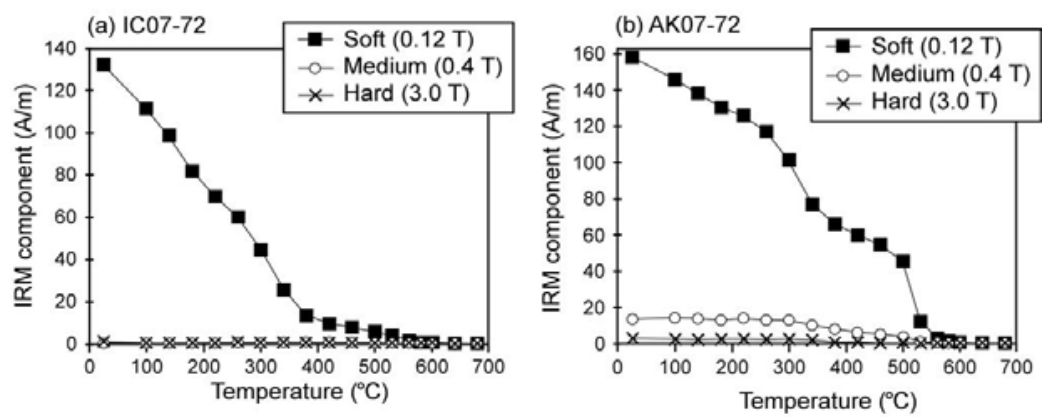

Fig. 9. Decay of three orthogonal IRM components during PThD for the NPFD specimens

For representative specimens, NRM was AF-demagnetized (peak field=100 mT), then isothermal remanent magnetization (IRM) was acquired using a pulse-magnetizer (MMPM10). According to the Lowrie's (1990) method, IRMs were successively imparted in three orthogonal directions under direct magnetic fields; 3.0, 0.4 and 0.12 T. Figure 9 presents PThD results of the orthogonal IRMs. It is clear that soft component with low coercive force $\left(\mathrm{H}_{\mathrm{C}}<0.12 \mathrm{~T}\right)$ is dominant and demagnetized under $580^{\circ} \mathrm{C}$. Medium and hard components have minor contribution, and demagnetized under $640{ }^{\circ} \mathrm{C}$. These results indicate that the single TRM component resides in titanomagnetite with a small amount of ilmenohematite, which is same as the previous reports for the NPFD (Itoh et al., 2003, 2008).

\subsection{Tectonic implications}

Itoh et al. $(2003,2008)$ reported that oblate AMS fabric and microscopic eutaxitic structure can be utilized as proxies of initial horizontal plane of the NPFD. Except for a case that the structural attitude was determined through outcrop observation (AK08), we regarded the microscopic eutaxitic structure as the primary data for tilt correction. However, AMS data were utilized in most cases (Table 4) since the eutaxitic structure was hardly defined by microscopic observation in the present study. Figure 10a and b show easterly and westerly deflections in tilt-corrected site-mean directions for the IC and AK areas, respectively. Figure 10c demonstrates that formation-mean direction for the IC area is deflected from a reference direction, whereas formation-mean direction for the AK area is indistinguishable from a reference direction of DRM of a widespread water-laid tephra correlated with the NPFD (Nagahashi et al., 2000). Because the sampling site of the tephra is out of the deformation zone in Central Japan (NKTZ), it is suggested that southern border of the shear deformation zone accompanied by clockwise rotational motion (CJSZ) is located between the IC and AK areas. It is also pointed out that rotation angles on both sides of the dextral Inohana fault show large scatter whereas an inclination statistics suggests concordant mean inclination for the study areas (Figure 10). Precision parameter $(\kappa)$ based on conventional Fisher statistics (41.1 for composite mean of IC and AK areas) is smaller than that obtained 
from an inclination statistics (Kono, 1980) (58.1 for composite dataset of IC and AK areas), a fact which implies that directional scatter is attributed to rotational motion around vertical axes. We, then, attempt to evaluate fault-related differential rotations of supracrustal layer.

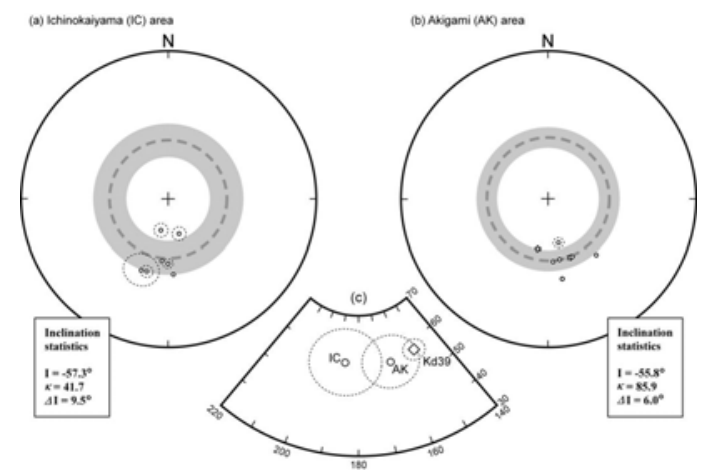

Fig. 10. Untilted site-mean directions of the IC (a) and AK (b) areas, and formation means obtained from the study areas together with reference direction (c). The diamond symbol is a reference direction (Kd39) after Nagahashi et al. (2000). All the data are plotted on the upper hemisphere of the equal-area projections. Dotted ovals are $95 \%$ confidence regions of mean directions. Parameters in enclosures are calculated using an inclination statistics (Kono, 1980), and $\Delta \mathrm{I}$, shown by shaded areas, is the $95 \%$ confidence limit of the mean inclination (dashed girdles)

Untilted site-mean directions of the NPFD show a wide variety in declinations suggestive of differential rotation around vertical axes (Figure 10a and b). To avoid the rotational bias, mean inclinations and their scatters calculated on the basis of an inclination statistics (Kono, 1980) are shown for the IC and AK areas in the figure. The mean inclination values are comparable with the previously reported values of the NPFD, and endorse reliability of the correction of tectonic tilting. As for the scatter in declinations in the IC area, spatial change seems to be associated with non-rigid deformation of nested-fault blocks. Figure 11a illustrates a simplified lithology and geologic structure around the IC area. A cross-plot in Figure $11 \mathrm{~b}$ clarifies that the easterly deflection (amount of clockwise rotation) decreases near nested vertical faults activated by dextral slips on the master Inohana fault, which is similar to a block deformation model after Itoh et al. (2003).

We described dense NNW-SSE fractures along the presumed nested faults F3, F4 and F5 (Figure 11c) that affects distribution of the NPFD, although clear indicators for lateral slip were not identified in outcrops. Thus development of subordinate faults along the Inohana fault controls the pattern of differential rotation in the IC area. As for the F1 and F2 faults running through the paleomagnetic sampling sites, we executed more detailed geological survey and found significant indications for existence of nested faults. Our result is summarized as Figure 12. Along the forestry road, we found highly brecciated pyroclastic flow deposits near the nested faults. On the F1 trend, we found a vertical fault contact between the Cretaceous Nohi Rhyolite and the Pleistocene NPFD without a chilled nonwelded margin. Although slip sense of the fault was not determined from the contact containing fault breccia and clay, it is noted that presence of nested faults predicted from paleomagnetic study has been confirmed on the basis of field evidences. 


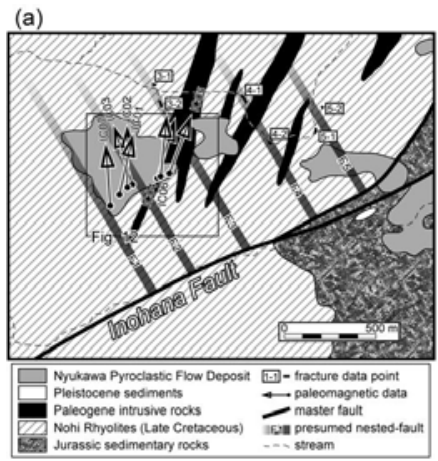

(b) nested-faults
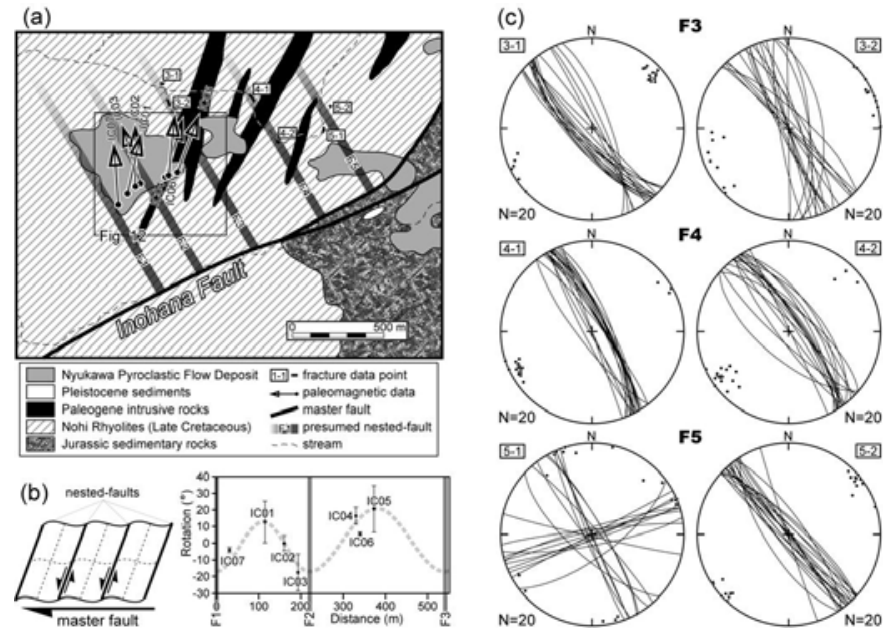

Fig. 11. (a) Declination data (arrows) of the IC site-mean directions. Simplified geology is after Yamada et al. (1985). Mapped area is shown in Fig. 7. (b) A deformation model of nested-fault blocks (Itoh et al., 2003) and rotation (R; polarity-converted untilted declination) as a function of distance along master Inohana fault. $\Delta \mathrm{R}$ is given as $\sin ^{-1}\left(\sin \alpha_{95} / \cos \mathrm{I}\right)$. (c) Fracture orientations on the presumed nested-faults. Fracture planes (great circles) and poles (dots) on outcrops are plotted on the lower hemisphere of the equal-area projections

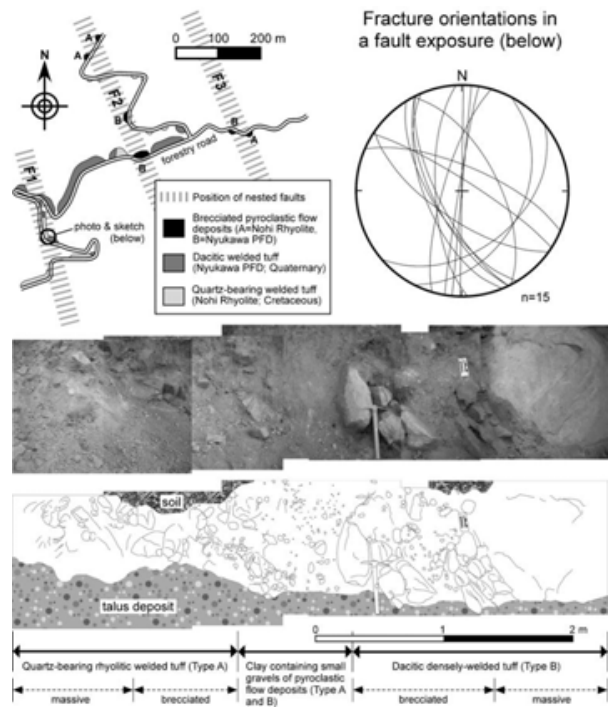

Fig. 12. Distribution of highly brecciated pyroclastic flow deposits on the nested faults along the forestry road (upper, left), and a photo and sketch of a vertical fault contact on the F1 trend between the Cretaceous Nohi Rhyolite (Type A) and the Pleistocene NPFD (Type B) without a chilled non-welded margin (lower). Fracture planes in the contact are plotted on lower hemisphere of an equal-area projection (upper, right). See Fig. 11 for mapped area 
As for the southern AK area, poor outcrop condition hindered us from identifying nested faults controlling differential rotation. Large scatter in declinations, however, implies a similar mechanism of non-rigid deformation. On the other hand, westerly-deflected formation mean suggests that amount of rotation decreases on the southern side of the Inohana fault. Our study demonstrates significance of an active fault that acts as boundary of a regional deformation zone (CJSZ), and, at the same time, controls localized deformation pattern by means of development of subordinate faults.

\section{Integration: cumulative strain mapping based on a numerical model}

\subsection{Synopsis}

Active tectonic deformation is being studied in light of numerical modeling of the upper crust. For example, Katzman et al. (1995) constructed a three-dimensional model of the Dead Sea Basin along the African/Arabian transform plate boundary in order to understand the evolution of pull-apart basins. Itoh et al. (2008) also pursued a quantitative evaluation of pull-apart basin formation combining paleomagnetic data and dislocation modeling. Pullapart basins are found along major strike-slip faults throughout the world and their morphological character was summarized by Aydin \& Nur (1982).

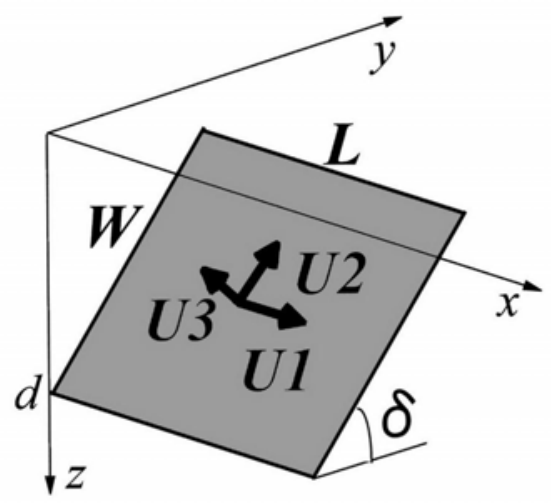

Fig. 13. Dislocation plane (plane painted by gray). $L, W, d$ and $\delta$ are the length, width, depth and dip of the fault. $U 1, U 2$ and $U 3$ are strike-slip, dip slip and tensile components of dislocation. Positive $U 1$ and $U 2$ correspond to left-lateral slip and reverse slip, respectively, with $0<\delta<\pi / 2$

In order to assess the relationship between motions on active faults and crustal deformation in the NKTZ, Central Japan, Itoh et al. (2008) executed detailed paleomagnetic study around the Takayama basin (Figure 1) that has been developed as a pull-apart sag at a stepping part of active faults. They attempted to detect subtle motions around intraplate active faults that have lower slip rates than transform plate boundaries (Katzman et al., 1995), and paleo/ rock magnetic measurements were made on the early Quaternary NPFD, one of numerous recent volcanic rocks outcropping in this region, and one for which a previous paleomagnetic studies have demonstrated the presence of a stable TRM signature and its 
suitability as an indicator of crustal deformation. Itoh et al. (2008) concentrated on the NPFD distributed around the Takayama Basin, which is located in the middle of the NE-SW deformation zone. As their result is characterized by quite complex rotation pattern at the termination of faults, a dislocation modeling was introduced for the quantitative interpretation of deformation mode in the tectonic zone.

Dislocation modeling is one of the simulation methods used for estimating crustal deformations, strains and tilts associated with fault motions (e.g., Chinnery, 1961; Okada, 1985, 1992; Segall, 2010). They are expressed as superpositions of analytical solutions for dislocation planes embedded in an isotropic elastic half-space (Figure 13). This modeling method is often used to construct fault models explaining crustal deformation due to earthquakes and volcanic activities (e.g., Miura et al., 2000; Lasserre et al., 2005). On the other hand, similar modeling has also been applied to tectonic interpretations of geological structures such as pull-apart basin (e.g., Rodgers, 1980; Kusumoto et al., 1999), as it is a simple calculation that represents the essential kinematic characteristics of regional tectonic movements, and does not require assumptions of dynamic friction over the fault plane or a specific physical slip mechanism.

\subsection{Vertical deformation field}
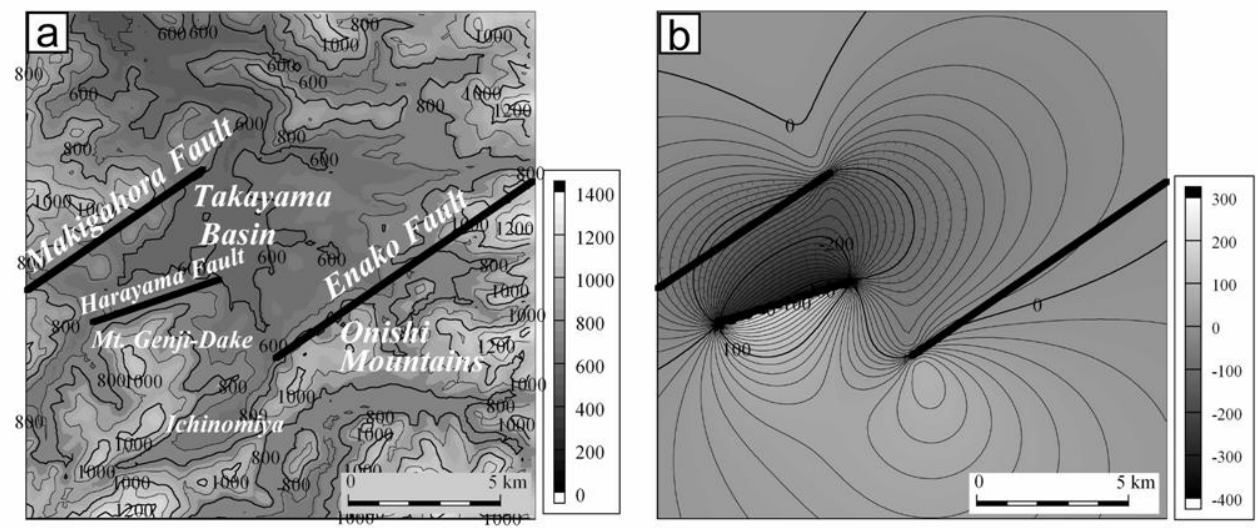

Fig. 14. (a) Topographic map with elevations given in meters. Bold lines indicate the fault locations represented as straight lines. (b) Vertical deformation field caused by slip on the Enako, Makigahora and Harayama faults. These fault motions are based on the fault parameters given in Table 5. Bold lines are simplified fault locations. The deformations are expressed in meters. See Fig. 1 for the study area of Itoh et al. (2008)

In our research procedures, dislocation modeling based on Okada's (1985) formula was employed, and the locations of the active faults were inferred from their traces at the surface. The Takayama Basin is a pull-apart depression formed by ongoing motion on active segments of the Enako and Makigahora faults (Figures 1 and 14a). The active portion of the Enako fault has moved eastward during the Quaternary. In contrast, the active segment of the Makigahora fault has retreated westward. Our model, then, introduced a secondary vertical-slip fault, the Harayama fault. It is located where an extensional strain field is formed by the lateral fault motions, and a type of secondary fault discussed by Shen et al. 
(1995). Hence, the initial distribution of vertical deformation in response to right-lateral and vertical motions of these three faults was estimated by dislocation modeling using the fault parameters shown in Table 5. In the simulations, we gave geological large slips on the dislocation planes by assigning small slip step by step, as the Okada's formulas are derived in an elastic range. We have assumed that fault motions occurred with a 100-year interval and that the terminations of the Enako and Makigahora faults have shifted in a direction out of the Takayama Basin at the rate of $0.05 \mathrm{~m} / 10^{2} \mathrm{yr}$. The other fault parameters required for the modeling are assigned as follows: the dip angle, width and depth of each fault are $90^{\circ}$, $15 \mathrm{~km}$ and $15 \mathrm{~km}$, respectively, and the Poisson's ratio of the crust is 0.25 . The width and depth values were determined from the hypocenters of recent earthquakes. The modeling results are shown in Figure 14b. Because the dislocation model employed in this study is defined within an isotropic elastic half-space, static deformation fields are presented and vertical deformation pattern is compared with topography. The result implies that motion on all three faults is required to account for geological structures in and around the Takayama Basin.

\begin{tabular}{lllllll}
\hline & $U 1$ & $U 2$ & $L$ & $W$ & $d$ & $\delta$ \\
\hline Enako Fault & -1.0 & 0.0 & Semi-infinite & 15.0 & 15.0 & 90.0 \\
& $\left(-0.05 \mathrm{~m} / 10^{2} \mathrm{yr}.\right)$ & & & & & \\
Makigahora Fault & -1.0 & 0.0 & Semi-infinite & 15.0 & 15.0 & 90.0 \\
& $\left(-0.05 \mathrm{~m} / 10^{2} \mathrm{yr}.\right)$ & & & & & \\
Harayama Fault & 0.0 & 0.5 & 2.25 & 15.0 & 15.0 & 90.0 \\
(western segment) & & $\left(0.05 \mathrm{~m} / 10^{2} \mathrm{yr}.\right)$ & & & & \\
Harayama Fault & 0.0 & 0.5 & 2.25 & 15.0 & 15.0 & 90.0 \\
(eastern segment) & & $\left(0.25 \mathrm{~m} / 10^{2} \mathrm{yr}.\right)$ & & & & \\
\hline
\end{tabular}

Table 5. Fault parameters for each fault in the study area

Positive $U 1$ and $U 2$ indicate left-lateral slip and reverse slip, respectively, with $0 \leq \delta \leq \pi / 2$.

The $U 3$ (opening) component of each fault is set to zero. Parameters, $U 1, U 2, L, W$ and $d$, are expressed in $\mathrm{km}$, and the fault dip angle, $\delta$, in degrees

\subsection{Spatial distribution of cumulative rotational motions}

Vertical-axis rotation $\left(\omega_{z}\right)$ is defined as follows (e.g., Jaeger, 1962);

$$
\omega_{z}=\frac{1}{2}\left(\frac{\partial u_{y}}{\partial x}-\frac{\partial u_{x}}{\partial y}\right)
$$

where $u_{x}$ and $u_{y}$ are displacement in the $x$ and $y$ directions, respectively. The vertical-axis rotation is independent of the elastic constants, and the direction and magnitude of the rotations due to fault motions are determined solely by the fault parameters.

The vertical-axis rotation estimated using a dislocation plane embedded in an elastic isotropic half-space is smaller than the amount of the observed vertical-axis rotation, because an elastic dislocation model gives only static deformation and strain fields. Thus, it is necessary to employ a modeling technique based on a viscoelastic theory that can 
accommodate temporal effects. Dislocation models embedded in a viscoelastic layer or in an elastic layer with a viscoelastic layer beneath have been proposed (e.g., Pollitz, 1992) and it has been shown that the deformation and strain fields they produce are dependent on the assumed viscoelastic structures, the fault type and fault length (e.g., Pollitz, 1992). On the other hand, Sonder et al. (1994) attempted to interpret paleomagnetic data observed in a shear zone under the pure shear deformation assumption by means of a thin viscous sheet model obeying a power law rheology discussed by England \& McKenzie (1983) and England \& Wells (1991). In our study field, it is difficult to justify the pure shear deformation assumption, and specific viscoelastic structures are unknown.

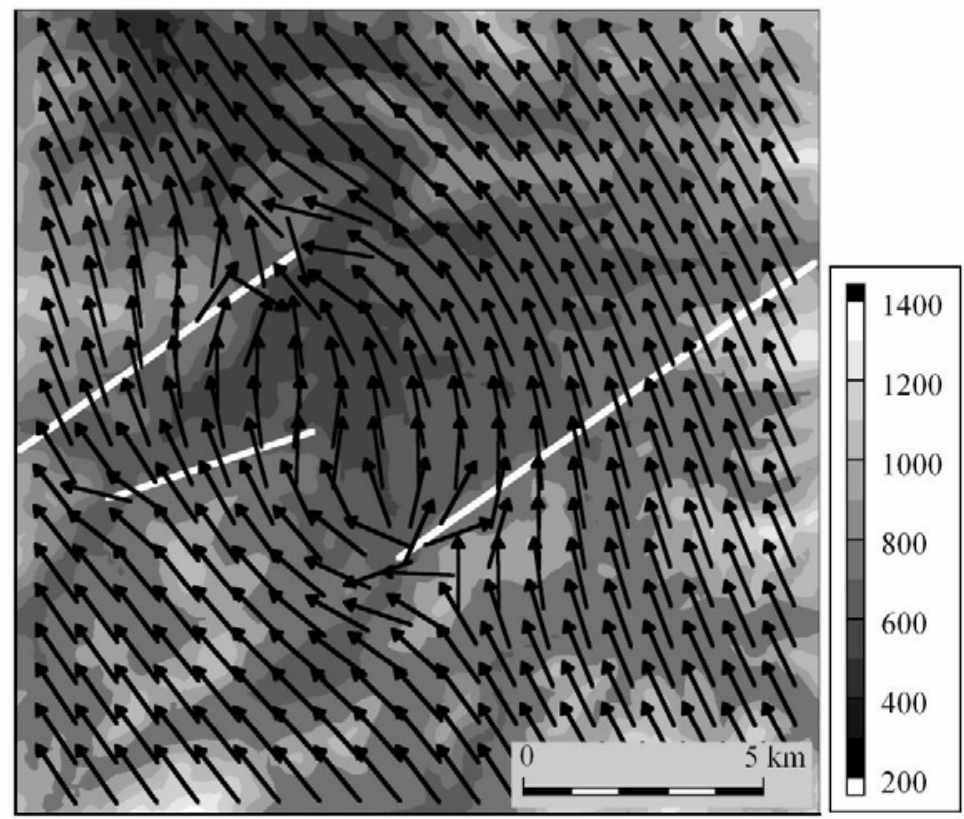

Fig. 15. Vertical-axis rotation field represented as vectors on the geographical map (elevations in meters). White bold lines indicate simplified fault locations. See Fig. 1 for the study area of Itoh et al. (2008)

Therefore, as a preliminary explanation, we have attempted to interpret the observed vertical-axis rotation pattern by introducing a suitable correction coefficient to the rotation field given by purely elastic dislocations. Because our study area is small, we have applied the correction coefficient uniformly to the calculated vertical-axis rotation. Following further trial and error we have found that if the correction coefficient is 10 , the calculated verticalaxis rotation can be compared with observed data.

Figure 15 shows the vertical-axis rotation fields estimated from calculations based on the fault parameters given in Table 5. This figure illustrates that all three faults have large rotations at their terminations. A counterclockwise rotation is formed at the terminations of the Makigahora and Enako faults, and clockwise rotation is distributed in the wide area except at these fault terminations. Conversely, the polarities of the vertical-axis rotations at 
both terminations of the Harayama fault are opposite. We found that the spatial distribution of cumulative rotation described by paleomagnetic study was restored based on the simplified model. Thus, the numerical modeling is useful to understand the causal relationship between fault motions and crustal deformation, and to predict development patterns of a tectonic zone.

\section{Conclusion}

Neotectonic case study executed on the Central Japan, which was generally regarded as an uplifted area under E-W compression, has presented a new interpretation for the history of crustal deformation. A comprehensive review of paleomagnetic data from the Neogene to Quaternary has delineated a shear deformation zone (CJSZ) crossing the ISTL, most conspicuous structural break from the viewpoint of geomorphology and geology. It is noteworthy that the CJSZ extends to the east of ISTL, an area which was believed to be a deformation zone bounded by reverse faults (Omine belt). Our new entry of paleomagnetic data suggests that the Omine belt was rotated clockwise before a remarkable tilt. Tectonic tilting of the study area is closely linked with commencement of vigorous uplift of the Central Japan and probable activation of reverse faulting on the ISTL. Radiometric ages of exhumed Quaternary pluton in the mountainous ranges constrain the initiation timing of E$\mathrm{W}$ contraction to be $1.4 \mathrm{Ma}$ (Harayama, 1992). On the other hand, paleomagnetic record obtained from the Kamitakara Pyroclastic Flow Deposit (Table 1) implies that clockwise rotation resumed in a part of CJSZ during late Quaternary.

Together with recent development of geodetic analyses, our result indicates that a tectonic switch has been working in the study area. Namely, crustal deformation of the Central Japan commenced under prevailing shear deformation along the NE-SW trending CJSZ, and was succeeded by a strong E-W contraction around the middle of Quaternary. Although the mechanism governing the temporal change in deformation modes is not clearly understood, the contractional regime waned in late Quaternary, and the present crustal strain is concentrated on the NKTZ defined on the basis of geodetic data, which is almost identical with the CJSZ, with negligible contribution of the ISTL. Thus the tectonic evolution is not controlled by a steady-state regime as was accepted in geological discussion, but to be interpreted on the assumption of transient tectonic architecture.

Next, closer look on the vertical-axis rotation pattern revealed by paleomagnetism implies progressive segmentation of upper crust along a master fault and deformation of rotated blocks bounded by nested-faults, presence of which was confirmed through field survey. A mid-crust low-velocity portion underlying the NKTZ (Figure 1) may have enhanced shear deformation and development of nested-faults in the brittle supracrustal layer. In order to understand how the density of fractures and width of a damage zone are determined, further quantitative research is required on an active fault, of which geophysical and geological properties have been determined in depth.

Computer simulation of crustal deformation is useful for the understanding of spatial distribution of strain, and prediction of future developments of a tectonic zone. Quantitative dislocation models successfully replicate complicated paleomagnetic rotation history suggesting that it has been controlled by kinematic transitions between active fault segments in the study area. Hence, the present study demonstrates that a quantitative description of crustal strain, provided by means of paleomagnetism and geomorphology, gives a firm basis of parameter setting during the course of a numerical modeling. Our 
approach is expected to be effective for tectonic studies pursuing evolution of crustal structure through longer geologic periods, and for establishment of methodology of tectonic research integrating geology, geomorphology and geophysics.

Several decades have passed since a quantitative deformation model of the Japanese Islands was submitted on the basis of geodetic analyses. It seems, however, that comprehensive geologic investigation in order to accommodate short- / long-term aspects of tectonic events has not been organized. Mid-crust P-wave velocity anomaly on the NKTZ inevitably suggests accumulation of crustal strain in geologic time-scale. Concept of tectonic switch should be verified on the basis of geologic survey for realistic evaluation of seismic risk of active faults. Temporal change in deformation modes results in fluctuation of slip rates on active faults, and affects the evaluation derived from average slip rates.

\section{Acknowledgments}

The authors would like to thank N. Ishikawa and A. Hayashida for the use of his paleomagnetic laboratory at Kyoto University and thoughtful discussion during the course of the tectonic study in Japan, respectively. Sincere thanks are due to Y. Nagahashi for his support in field survey. Laboratory/field assistances of K. Sumita, M. Tamaki, T. Miyazaki, Y. Takiuchi, S. Oshimbe, S. Nishizaki and T. Fujiwara are gratefully acknowledged.

\section{References}

Aydin, A. \& Nur, A. (1982). Evolution of pull-apart basins and their scale independence. Tectonics, Vol. 1, pp. 91-105.

Beck, M.E. (1980). Paleomagnetic record of plate-margin tectonic processes along the western edge of North America. eburnal of Geophysical Research, Vol.85, pp. 71157131.

Chinnery, M.A. (1961). The deformation of the ground around surface faults. Bulletin of Seismological Society of America, Vol.51, pp. 355-372.

Demarest, H.H. (1983). Error analysis for the determination of tectonic rotation from paleomagnetic data. eburnal of Geophysical Research, Vol.88, pp. 4321-4328.

England, P. \& McKenzie, D. (1983). Correction to: a thin viscous sheet model for continental deformation. Geophysical eburnal of the Royal Astronomical Society, Vol.73, pp. 523532.

England, P. \& Wells, R.E. (1991). Neogene rotations and quasicontinuous deformation of the Pacific northwest continental margin. Geology, Vol.19, pp. 979-981.

Harayama, S. (1992). Youngest exposed granitoid pluton on Earth: cooling and rapid uplift of the Pliocene-Quaternary Takidani Granodiorite in the Japan Alps, central Japan. Geology, Vol.20, pp. 657-660.

Hashimoto, M. (1990). Horizontal strain rate in the Japanese islands during interseismic period deduced from geodetic surveys (Part 1): Honshu, Shikoku and Kyushu. eburnal of Seismological Society of elpan, Vol.43, pp. 13-26. (in Japanese with English abstract)

Hashimoto, M. \& Jackson, D.D. (1993). Plate tectonics and crustal deformation around the Japanese Islands. eburnal of Geophysical Research, Vol.98, pp. 16149-16166. 
Hayashida, A., Kamata, H. \& Danhara, T. (1996). Correlation of widespread tephra deposits based on paleomagnetic directions: link between a volcanic field and sedimentary sequences in Japan. Quaternary International, Vol.34-36, pp. 89-98.

Heki, K. \& Miyazaki, S. (2001). Plate convergence and long-term crustal deformation. Geophysical Research Letters, Vol.28, pp. 2313-2316.

Huzita, K. (1980). Role of the Median Tectonic Line in the Quaternary tectonics of the Japanese islands. Memoir of Geological Society of Jopan, Vol.18, pp. 129-153.

Hyodo, M. \& Hirahara, K. (2003). A viscoelastic model of interseismic strain concentration in Niigata-Kobe Tectonic Zone of central Japan. Earth Planets Space, Vol.55, pp. 667675.

Iidaka, T., Kato, A., Kurashimo, E., Iwasaki, T., Hirata, N., Katao, H., Hirose, I. \& Miyamachi, H. (2009). Fine structure of P-wave velocity distribution along the Atotsugawa fault, central Japan. Tectonophysics, Vol.472, pp. 95-104.

Iio, Y., Sagiya, T., Kobayashi, Y. \& Shiozaki, I. (2002). Water-weakened lower crust and its role in the concentrated deformation in the Japanese Islands. Earth and Planetary Science Letters, Vol.203, pp. 245-253.

Itoh, Y. \& Amano, K. (2004). Progressive segmentation and systematic block rotation within a plutonic body: palaeomagnetism of the Cretaceous Kurihashi granodiorite in northeast Japan. Geophysical eburnal International, Vol.157, pp. 128-140.

Itoh, Y. \& Danhara, T. (2008). Tephrochronological, paleomagnetic and rock magnetic properties of the Shiratsuchidani volcanic ash in the Pleistocene Kobiwako Group, central Japan. Quaternary Research, Vol.47, pp. 329-338.

Itoh, Y. \& Hayakawa, H. (1988). Magnetostratigraphy of Neogene rocks around the Yatsuo area in Toyama Prefecture, Japan. eburnal of the Geological Society of ebopan, Vol.94, pp. 515-525. (in Japanese with English abstract)

Itoh, Y. \& Ito, Y. (1989). Confined ductile deformation in the Japan arc inferred from paleomagnetic studies. Tectonophysics, Vol.167, pp. 57-73.

Itoh, Y. \& Kimura, H. (2004). Paleomagnetism of a pyroclastic flow deposit and its correlative widespread tephra in central Japan: possible tectonic rotation since the late Pleistocene. Island Arc, Vol.13, pp. 110-118.

Itoh, Y. \& Watanabe, M. (1997). Magnetostratigraphy of Neogene rocks around the Himi area in Toyama Prefecture, Japan. Bulletin of the Geological Survey of etopan, Vol.48, pp. 339-346. (in Japanese with English abstract)

Itoh, Y., Kimura, H. \& Doshida, S. (2003). Active strike-slip faulting and macroscopically nonrigid deformation of volcanic rocks in central Japan inferred from a paleomagnetic study. Tectonophysics, Vol.374, pp. 81-98.

Itoh, Y., Kusumoto, S. \& Furubayashi, T. (2008). Quantitative evaluation of Quaternary crustal deformation around the Takayama Basin, central Japan: A paleomagnetic and numerical modeling approach. Earth and Planetary Science Letters, Vol.267, pp. 517-532.

Itoh, Y., Miyazaki, T. \& Nishizaki, S. (2007). Quaternary tectonic rotation in central Japan: paleomagnetism of the Eboshidake volcanic rocks. Island Arc, Vol.16, pp. 457-464.

Iwaki, H. \& Hayashida, A. (2003). Paleomagnetism of Pleistocene widespread tephra deposits and its implication for tectonic rotation in central Japan. The Island Arc, Vol.12, pp. 46-60. 

Sedimentary Basins and Island Arcs

Jaeger, J.C. (1962). Elasticity, Fracture and Flow with Engineering and Geological Applications (2ndEdition), Methuen, London, 212 pp.

Kato, A., Iidaka, T., Iwasaki, T., Hirata, N. \& Nakagawa, S. (2010). Reactivation of boundary faults within a buried ancient rift system by ductile creeping of weak shear zones in the overpressured lower crust: The 2004 mid-Niigata Prefecture Earthquake. Tectonophysics, Vol.486, pp. 101-107.

Katzman, R., ten Brink, U.S. \& Lin, J. (1995). Three-dimensional modeling of pull-apart basins: implications for the tectonics of the Dead Sea Basin. eburnal of Geophysical Research, Vol.100, pp. 6295-6312.

Kimura, H., Itoh, Y. \& Tsutsumi, H. (2004). Quaternary strike-slip crustal deformation around an active fault based on paleomagnetic analysis: a case study of the Enako fault in central Japan. Earth and Planetary Science Letters, Vol.226, pp. 321-334.

Kirschvink, J.L. (1980). The least-squares line and plane and the analysis of palaeomagnetic data. Geophysical burnal of the Royal Astronomical Society, Vol.62, pp. 699-718.

Kono, M. (1980). Statistics of paleomagnetic inclination data. eburnal of Geophysical Research, Vol.85, pp. 3878-3882.

Kosaka, T. \& Arai, K. (1982). Tertiary-Quaternary Systems in the western margin of the Northern Fossa Magna (2): Stratigraphical and sedimentological studies of the Tertiary-Quaternary Systems in the upper reaches of the River Hime, Nagano Prefecture. Monograph of the Association for the Geological Collaboration in elpan, Vol.24, pp. 181-198. (in Japanese with English abstract)

Kusumoto, S., Takemura, K., Fukuda, Y. \& Takemoto, S. (1999). Restoration of the depression structure at the eastern part of central Kyushu, Japan, by means of the dislocation modeling. Tectonophysics, Vol.302, pp. 287-296.

Lasserre, C., Peltzer, G., Crampe, F., Klinger, Y., Van der Woerd, J. \& Tapponnier, P. (2005). Coseismic deformation of the $2001 \mathrm{Mw}=7.8$ Kokoxili earthquake in Tibet, measured by synthetic aperture radar interferometry. eburnal of Geophysical Research, Vol.110, B12408, doi:10.1029/2004JB003500.

Lowrie, W. (1990). Identification of ferromagnetic minerals in a rock by coercivity and unblocking temperature properties. Geophysical Research Letters, Vol.17, pp. 159-162.

Machida, H. \& Arai, F. (2003). Atlas of Tephra in and around chopan (Revised Edition), University of Tokyo Press, Tokyo, 336 pp. (in Japanese)

Mattei, M., D’Agostino, N., Zananiri, I., Kondopoulou, D., Pavlides, S. \& Spatharas, V. (2004). Tectonic evolution of fault-bounded continental blocks: comparison of paleomagnetic and GPS data in the Corinth and Megara basins (Greece). cburnal of Geophysical Research, Vol.109, B02106. doi:10.1029/2003JB002506.

Mazzotti, S., Le Pichon, X. \& Henry, P. (2000). Full interseismic locking of the Nankai and Japan-west Kurile subduction zones: an analysis of uniform elastic strain accumulation in Japan constrained by permanent GPS. eburnal of Geophysical Research, Vol.105, pp. 13159-13177.

Miura, S., Ueki, S., Sato, T., Tachibana, K. \& Hamaguchi, H. (2000). Crustal deformation associated with the 1998 seismo-volcanic crisis of Iwate volcano, northeastern Japan, as observed by a dense GPS network. Earth Planets Space, Vol.52, pp. 10031008.

Miyazaki, S. \& Heki, K. (2001). Crustal velocity field of southwest Japan: subduction and arc-arc collision. eburnal of Geophysical Research, Vol.106, pp. 4305-4326. 
Nagahashi, Y., Satoguchi, Y. \& Yoshikawa, S. (2000). Correlation and stratigraphic eruption age of the pyroclastic flow deposits and widespread volcanic ashes intercalated in the Pliocene-Pleistocene strata, central Japan. Cburnal of the Geological Society of etopan, Vol.106, pp. 51-69. (in Japanese with English abstract)

Nakajima, J. \& Hasegawa, A. (2007). Deep crustal structure along the Niigata-Kobe Tectonic Zone, Japan: its origin and segmentation. Earth Planets Space, Vol.59, e5-e8.

Niitsuma, S., Niitsuma, N. \& Saito, K. (2003). Evolution of the Komiji Syncline in the North Fossa Magna, central Japan: Paleomagnetic and K-Ar age insights. The Island Arc, Vol.12, pp. 310-323.

Okada, Y. (1985). Surface deformation due to shear and tensile faults in a halfspace. Bulletin of Seismological Society of America, Vol.75, pp. 1135-1154.

Okada, Y. (1992). Internal deformation due to shear and tensile faults in a halfspace. Bulletin of Seismological Society of America, Vol.82, pp. 1018-1040.

Pollitz, F.F. (1992). Postseismic relaxation theory on the spherical earth. Bulletin of Seismological Society of America, Vol.82, pp. 422-453.

Research Group for Active Faults (1991). The Active Faults in chpan: Sheet Maps and Inventories (Revised Edition), University of Tokyo Press, Tokyo, 437 pp. (in Japanese with English abstract)

Reynolds, R.L. (1979). Comparison of the TRM of the Yellowstone Group and the DRM of some Pearlette ash beds. eburnal of Geophysical Research, Vol.84, pp. 4525-4532.

Rodgers, D.A. (1980). Analysis of pull-apart basin development produced by en echelon strike-slip faults. Special Publication of International Association of Sedimentology, Vol.4, pp. 27-41.

Sagiya, T. (2004). A decade of GEONET: 1994-2003 - The continuous GPS observation in Japan and its impact on earthquake studies -. Earth Planets Space, Vol.56, xxix-xli.

Sagiya, T., Miyazaki, S. \& Tada, T. (2000). Continuous GPS array and present-day crustal deformation of Japan. Pure Applied Geophysics, Vol.157, pp. 2303-2322.

Savage, J.C. (1983). A dislocation model for strain accumulation and release at a subduction zone. eburnal of Geophysical Research, Vol.88, pp. 4984-4996.

Segall, P. (2010). Earthquake and Volcano Deformation, Princeton University Press, Princeton and Oxford, $432 \mathrm{pp}$.

Seno, T., Sakurai, T. \& Stein, S. (1996). Can the Okhotsk plate be distinguished from the North American plate? eburnal of Geophysical Research, Vol.101, pp. 11305-11315.

Shen, B., Stephansson, O., Einstein, H.H. \& Ghahreman, B. (1995). Coalescence of fractures under shear stresses in experiments. eburnal of Geophysical Research, Vol.100, pp. 5975-5990.

Shimazaki, K. \& Zhao, Y. (2000). Dislocation model for strain accumulation in a plate collision zone. Earth Planets Space, Vol.52, pp. 1091-1094.

Sonder, L.J., Jones, C.H., Salyards, S.L. \& Murphy, K.M. (1994). Vertical axis rotations in the Las Vegas Valley Shear Zone, southern Nevada: paleomagnetic constraints on kinematics and dynamics of block rotations. Tectonics, Vol.13, pp. 769-788.

Toya, Y. \& Kasahara, M. (2005). Robust and exploratory analysis of active mesoscale tectonic zones in Japan utilizing the nationwide GPS array. Tectonophysics, Vol.400, pp. 2753. 
Wang, Z. \& Zhao, D. (2006). Seismic images of the source area of the 2004 Mid-Niigata Prefecture earthquake in Northeast Japan. Earth and Planetary Science Letters, Vol.244, pp. 16-31.

Working Group for Compilation of 1:2,000,000 Active Faults Map of Japan (2000). New 1:2,000,000 active faults map of Japan. Active Fault Research, Vol.19, pp. 3-12. (in Japanese)

Xia, S., Zhao, D. \& Qiu, X. (2008). The 2007 Niigata earthquake: Effect of arc magma and fluids. Physics of the Earth and Planetary Interiors, Vol.166, pp. 153-166.

Yamada, N., Adachi, M., Kajita, S., Harayama, S., Yamazaki, H. \& Bunno, M. (1985). Geology of the Takayama District, Quadrangle Series Scale 1:50,000, Geological Survey of Japan, Tsukuba, 111 pp. (in Japanese with English summary)

Yamada, N. \& Kobayashi, T. (1988). Geology of the Ontakesan District, Quadrangle Series Scale 1:50,000, Geological Survey of Japan, Tsukuba, 136 pp. (in Japanese with English summary)

Yamasaki, T. \& Seno, T. (2005). High strain zone in central Honshu resulting from the viscosity heterogeneities in the crust and mantle. Earth and Planetary Science Letters, Vol.232, pp. 13-27. 


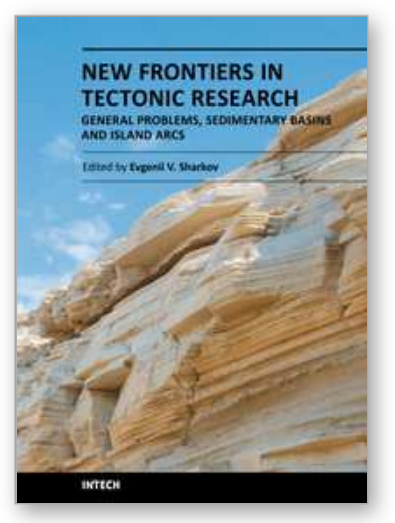

\author{
New Frontiers in Tectonic Research - General Problems, \\ Sedimentary Basins and Island Arcs \\ Edited by Prof. Evgenii Sharkov
}

ISBN 978-953-307-595-2

Hard cover, 350 pages

Publisher InTech

Published online 27, July, 2011

Published in print edition July, 2011

This book is devoted to different aspects of tectonic research. Syntheses of recent and earlier works, combined with new results and interpretations, are presented in this book for diverse tectonic settings. Most of the chapters include up-to-date material of detailed geological investigations, often combined with geophysical data, which can help understand more clearly the essence of mechanisms of different tectonic processes. Some chapters are dedicated to general problems of tectonics. Another block of chapters is devoted to sedimentary basins and special attention in this book is given to tectonic processes on active plate margins.

\title{
How to reference
}

In order to correctly reference this scholarly work, feel free to copy and paste the following:

Yasuto Itoh, Shigekazu Kusumoto, Kazunori Miyamoto and Yoshiyuki Inui (2011). Short- / Long-Term Deformation of Upper Crust: Integrated and Quantitative Approach for Neotectonics, New Frontiers in Tectonic Research - General Problems, Sedimentary Basins and Island Arcs, Prof. Evgenii Sharkov (Ed.), ISBN: 978953-307-595-2, InTech, Available from: http://www.intechopen.com/books/new-frontiers-in-tectonic-researchgeneral-problems-sedimentary-basins-and-island-arcs/short-long-term-deformation-of-upper-crust-integratedand-quantitative-approach-for-neotectonics

\section{INTECH}

open science | open minds

\section{InTech Europe}

University Campus STeP Ri

Slavka Krautzeka 83/A

51000 Rijeka, Croatia

Phone: +385 (51) 770447

Fax: +385 (51) 686166

www.intechopen.com

\section{InTech China}

Unit 405, Office Block, Hotel Equatorial Shanghai

No.65, Yan An Road (West), Shanghai, 200040, China

中国上海市延安西路65号上海国际贵都大饭店办公楼 405 单元

Phone: +86-21-62489820

Fax: +86-21-62489821 
(C) 2011 The Author(s). Licensee IntechOpen. This chapter is distributed under the terms of the Creative Commons Attribution-NonCommercialShareAlike-3.0 License, which permits use, distribution and reproduction for non-commercial purposes, provided the original is properly cited and derivative works building on this content are distributed under the same license. 